\title{
Re-evaluation of the surface ruptures of the November 1951 earthquake series in eastern Taiwan, and its neotectonic implications
}

\author{
J. Bruce H. Shyu ${ }^{\text {a,*, Ling-Ho Chung }}{ }^{b}$, Yue-Gau Chen ${ }^{b}$, Jian-Cheng Lee ${ }^{c}$, Kerry Sieh ${ }^{\text {a }}$ \\ ${ }^{a}$ Tectonics Observatory, Division of Geological and Planetary Sciences, California Institute of Technology, Pasadena, CA 91125, USA \\ ${ }^{\mathrm{b}}$ Department of Geosciences, National Taiwan University, Taipei, Taiwan \\ ${ }^{\mathrm{c}}$ Institute of Earth Sciences, Academia Sinica, Taipei, Taiwan
}

Received 9 November 2004; received in revised form 14 November 2005; accepted 27 July 2006

\begin{abstract}
The earthquakes of November 1951 constitute the most destructive seismic episode in the recorded history of the Longitudinal Valley, eastern Taiwan. However, information about their source parameters is sparse. To understand the relationship between the 1951 ruptures and new interpretations of the regional neotectonic architecture of the Longitudinal Valley, we re-evaluated the November 1951 ruptures by analyzing old documents, reports and photographs, and by interviewing local residents who experienced the earthquake. As a result, we have revised significantly the rupture map previously published. We divide the surface ruptures from south to north into the Chihshang, Yuli, and Rueisuei sections. The first shock of the 1951 series probably resulted from the Chihshang rupture, and the second shock probably resulted from the Yuli and Rueisuei ruptures. The lengths of these ruptures indicate that the two shocks had similar magnitudes. The Chihshang and Rueisuei ruptures are along segments of the Longitudinal Valley fault, a left-lateral oblique fault along which the Coastal Range thrusts westward over the Longitudinal Valley. The Yuli rupture, on the other hand, appears to be part of a separate, leftlateral strike-slip Yuli fault, which traverses the middle of the Longitudinal Valley. The complex behavior of these structures and interaction between them are important in understanding the future seismic hazard of the area.
\end{abstract}

(C) 2006 Elsevier Ltd. All rights reserved.

Keywords: Taiwan; Longitudinal Valley fault; Surface ruptures; Earthquake; Neotectonics

\section{Introduction}

The island of Taiwan occupies an awkward position along the boundary between the Eurasian and Philippine Sea plates, where subduction and collision are progressively consuming oceanic fragments of both the Eurasian and the Philippine Sea lithosphere (Fig. 1a). In the century or so of recorded history, Taiwan has experienced several strong and destructive earthquakes (e.g., Bonilla, 1975, 1977; Hsu, 1980; Cheng and Yeh, 1989), the most recent of which was the disastrous 1999 Chi-Chi earthquake (see, e.g., Chen et al., 2001). These are the seismic manifestation of an orogeny that has been in progress for the past several million years (e.g.,

\footnotetext{
* Corresponding author. Tel.: +1 626395 6177; fax: +1 6263951740 .

E-mail address: jbhs@gps.caltech.edu (J.B.H. Shyu).
}

Ho, 1986; Teng, 1987, 1990, 1996). Along the narrow, northsouth Longitudinal Valley suture in eastern Taiwan, the Luzon volcanic island arc is actively accreting to the metamorphic core of the island (e.g., Shyu et al., 2005a; Fig. 1). Almost half a century before the 1999 earthquake, an earthquake series in the Longitudinal Valley dramatized the important role the valley plays in the overall neotectonics of Taiwan. This series included three magnitude 7 earthquakes centered near the northern end of the valley on 22 October 1951 and two events larger than magnitude 6 on 25 November 1951, which shook the middle part of the valley most severely. Onland surface ruptures approximately $15 \mathrm{~km}$ long at the northern end of the valley accompanied the October earthquakes, and more than $60 \mathrm{~km}$ of surface rupture in the central part of the Longitudinal Valley accompanied the November earthquakes (e.g., Hsu, 1962; Yu, 1997). Together, the five earthquakes killed more than 80 people and 
a

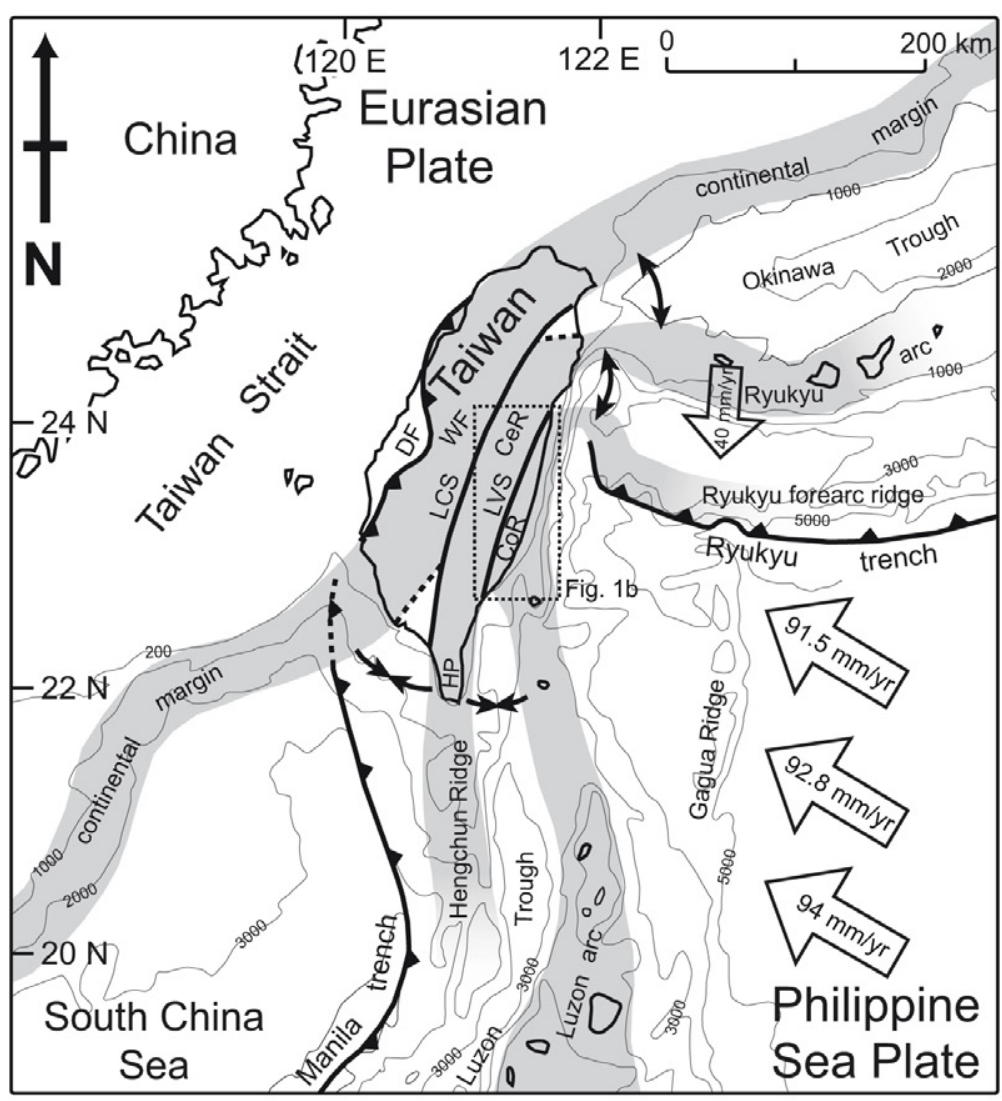

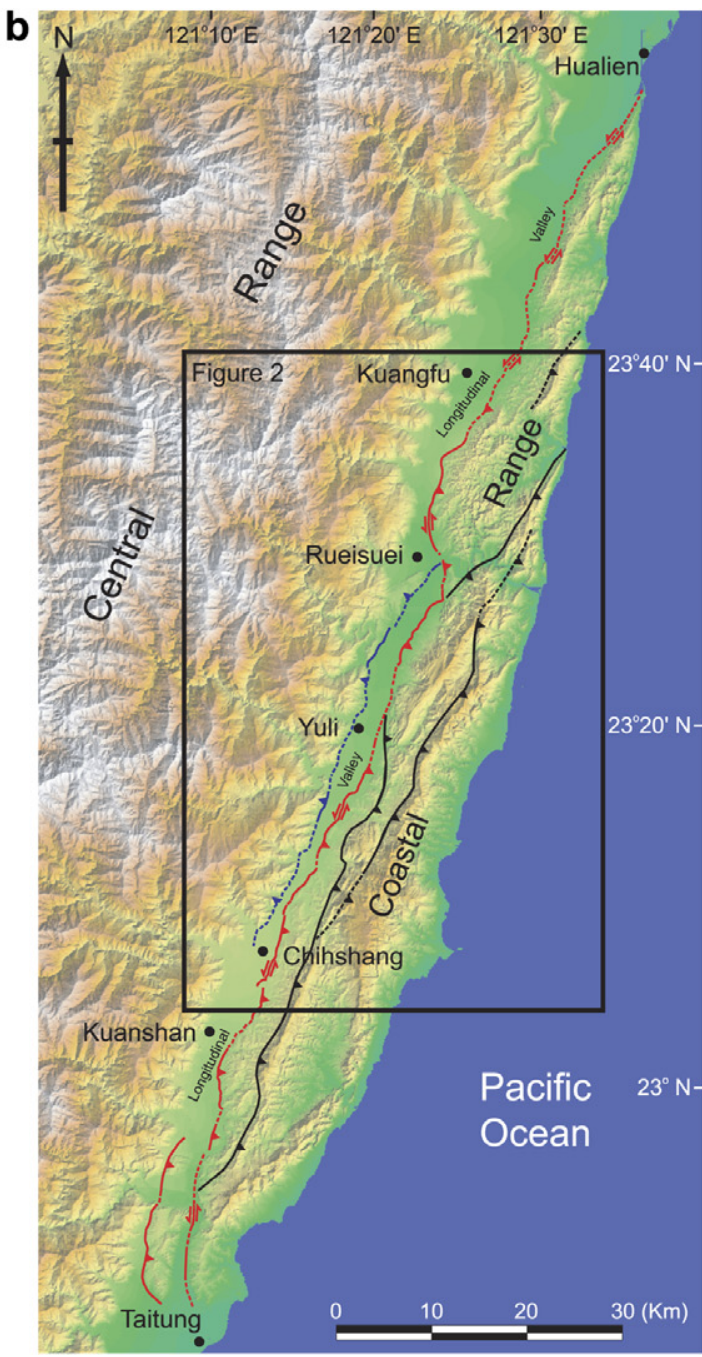

Fig. 1. (a) Taiwan is experiencing a transitory tandem suturing of a volcanic arc and a sliver of continental crust to the Asian continental margin. The 1951 earthquakes resulted from failure of faults along the Longitudinal Valley suture (LVS), the eastern of the two sutures. This suture is developing by the oblique collision of the Luzon volcanic arc into a narrow strip of continental crust. Adapted from Shyu et al. (2005a). Current velocity vectors of the Philippine Sea plate relative to South China, at $124^{\circ} \mathrm{E}$ and $20^{\circ}, 21^{\circ}$, and $22^{\circ} \mathrm{N}$, are calculated using the Recent plate velocity model (REVEL) of Sella et al. (2002). Current velocity vector of the Ryukyu arc adapted from Lallemand and Liu (1998). DF, deformation front; LCS, Lishan-Chaochou suture; WF, Western Foothills; CeR, Central Range; CoR, Coastal Range; HP, Hengchun Peninsula. (b) Map of major structures along the Longitudinal Valley, between the Central and Coastal Ranges. The east-dipping Longitudinal Valley fault (in red) and the west-dipping Central Range fault (in blue) are the two major active fault systems along the valley. Several major bedrock faults within the Coastal Range (in black) are also shown.

destroyed thousands of houses (Hsu, 1980; Cheng and Yeh, 1989), thus constituting the most disastrous seismic event in eastern Taiwan in recorded history.

Despite their pre-eminence in Taiwan's seismic history, we know little about these earthquakes. The November doublet and its surface ruptures are particularly obscure. Although casualties were not as large as those from the October earthquakes, principally because the events in November occurred in a rural part of the countryside, the surface ruptures of the November earthquakes were longer. However, the remoteness of the locality at that time hampered immediate investigation and detailed mapping of the ruptures. Thus, the only map of the November 1951 surface ruptures has been an approximately 1:2,000,000-scale figure published more than ten years after the earthquakes (Hsu, 1962). There have been several subsequent attempts to investigate active faults in the Longitudinal Valley (e.g., Hsu and Chang, 1979; Shih et al., 1983; Yang, 1986; Chu and $\mathrm{Yu}, 1997$; Chang et al., 1998; Lin et al., 2000). Nonetheless, most of these efforts either confused the 1951 ruptures with fault scarps that did not rupture in 1951, mapped only short segments of the 1951 rupture, or used erroneous information in compiling rupture locations. For example, some of these compilers considered the collapse of houses and bridges to indicate ground ruptures through these structures. On other maps, landslides reported by local witnesses or visible in photographs taken after the earthquakes appear as tectonic ruptures.

Recently, more detailed maps of the active structures of the Longitudinal Valley have been produced (e.g., Shyu et al., 2002, 2005b). These new efforts have stimulated us to attempt compilation of a more detailed and accurate map 
of the 1951 ruptures, in order to gain a better understanding of their relationship to the active faults of the valley and their neotectonic roles. The most important question we attempt to address is whether the November 1951 events occurred along any of the major structures of the Longitudinal Valley. If so, did the rupture involve all or just a subset of these structures? The answer to this question has important implications for the evaluation of seismic hazard potential in the area.

In our attempt to re-evaluate the surface ruptures, our principle sources have been the published literature, vintage photographs and interviews of local residents. We have examined all available scientific and non-scientific reports on the earthquakes, including a number of newspaper reports written after the earthquakes. Also, we have examined many old photographs taken after the earthquakes, searching for evidence of surface rupture. Some, but not all, of these photographs appeared in earlier reports (Taiwan Weather Bureau, 1952; Chu and Yu, 1997; Yu, 1997). These photographs were taken by several different investigators, in locations wherever surface deformation was noticed. Fortunately, although not heavily populated, there had already been many small villages along the Longitudinal Valley. Thus these photographs should reveal most of the surface ruptures. We have made a considerable effort to determine the locations where these photographs were taken, particularly by checking in the field for the topographic features shown in the photographs. Moreover, we conducted interviews with more than 40 local residents who experienced the earthquakes and had information about the location of surface ruptures and other aspects of the earthquakes. A complete compilation of these data appears in Chung (2003). In this brief paper, we present the summary of these results.

Although we have attempted to ensure the reliability of all this information, some uncertainties remain. Many reports in the literature are, for example, too vague to determine whether or not they are reliable. Many photographs cannot be assigned a certain location, because of agricultural modifications in the decades after the earthquakes or lack of distinctive landmarks. Also, some of the information we acquired in the interviews was vague, uncertain, or even contradictory. Nonetheless, by sifting all of the information, we have been able to improve significantly our understanding of the ruptures associated with the earthquake.

\section{Tectonic background of the Longitudinal Valley}

The Longitudinal Valley in eastern Taiwan is located between two major tectonic blocks (Fig. 1b). To the east is the Coastal Range, an assemblage of Miocene through early Pliocene volcanic arc rocks and associated turbidite deposits, mélange, and fringing-reef limestone (Chen, 1988; Ho, 1988). These rocks are similar to rocks that constitute the remnant of the Luzon island arc immediately to the south and the sediments of the adjacent sea floor. Thus, the rocks of the Coastal Range appear to represent a highly shortened forearc basin and volcanic arc (e.g., Chang et al., 2001). On the western side of the Longitudinal Valley is the eastern flank of the Central Range, which is composed of Mesozoic to Paleogene low-grade metamorphic rocks, predominantly schists and slates (Ho, 1988). The contrast in the constitution of the two ranges demonstrates that the intervening long, linear Longitudinal Valley occupies a major tectonic suture (e.g., York, 1976; Teng, 1990). Coarse late Quaternary clastic fluvial sediments fill the valley. The thickness of these sediments is unknown, but is likely more than $1 \mathrm{~km}$ (e.g., Chen et al., 1974; Chen, 1976).

The dominant neotectonic element of this part of the island is the east-dipping Longitudinal Valley fault, which traverses the eastern edge of the valley (Fig. 1b). It is characterized by high rates of sinistral reverse motion along its

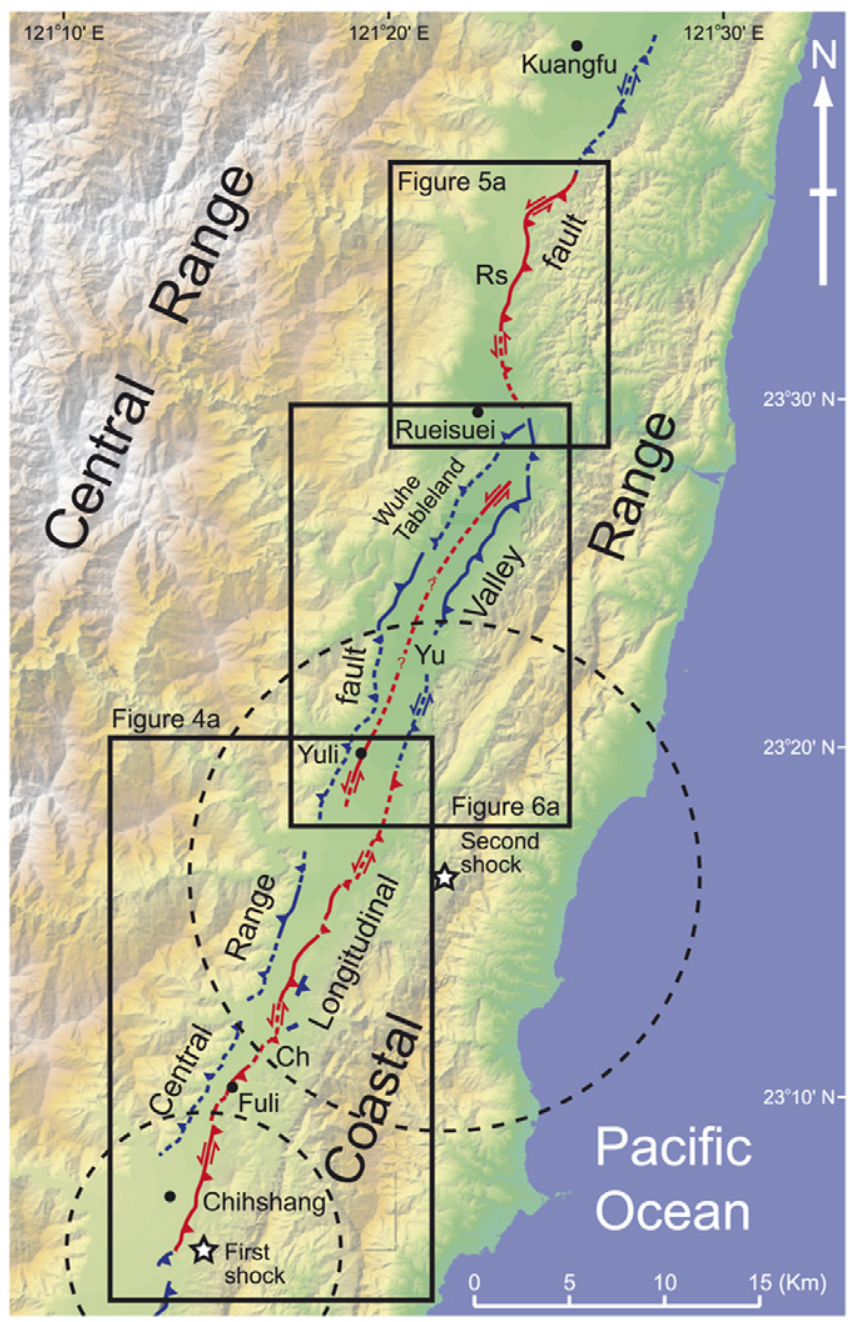

Fig. 2. Shaded relief map showing the active structures in the middle part of the Longitudinal Valley, between the Central and Coastal Ranges. Our estimate of the extent of the November 1951 ruptures is shown in red. Major active reverse faults and flexures that did not rupture in 1951 are shown in blue. Modified from Shyu et al. (2002, 2005b) and unpublished results of J.B.H. Shyu and L.-H. Chung. Ch, Chihshang rupture; Yu, Yuli rupture; Rs, Rueisuei rupture. Dashed faults are inferred. White stars are relocated epicenters of the November 1951 earthquakes, after Cheng et al. (1996), with their uncertainties shown as dashed circles. 
southern two-thirds and mostly sinistral motion along its northern one-third (Shyu et al., 2005b). The geomorphic manifestation of this fault is clear along most of the valley, but it is rather complex, especially along its southern twothirds. Distinctive tectonic landforms include discontinuous scarps that range up to several meters high along the range front and are lobate and irregular in plan view. These are commonly associated with east-tilted surfaces on the hanging-wall block. Along most of the valley, these thrust-fault scarps are also accompanied by numerous secondary anticlines and synclines in the hanging-wall block.

Another major active structure along the southern twothirds of the valley is a reverse fault that dips westward, beneath the eastern flank of the Central Range (Fig. 1b). This fault, named the Central Range fault by Biq (1965), may be the major structure along which rapid uplift of the eastern flank of the Central Range is occurring (e.g., Shyu et al., 2005b, 2006). Geomorphic evidence of this active fault includes a straight eastern flank of the Central Range along the southern two-thirds of the Longitudinal Valley and fluvial terraces that are perched tens to hundreds of meters above modern streambeds along a long segment of the range front. The most prominent feature among these is the Wuhe Tableland near Rueisuei in the middle of the valley (Shyu et al., 2002, 2006; Fig. 2).

Recent geodetic measurements show that the Longitudinal Valley is narrowing at a rate of about $40 \mathrm{~mm}$ yr-1 (e.g., $\mathrm{Yu}$ et al., 1997). Creepmeter measurements show that the Longitudinal Valley fault zone near the town of Chihshang (Figs. 1a and 2) is creeping at a rate of about $20 \mathrm{~mm}$ yr-1 (Angelier et al., 1997; Lee et al., 2001). Inversions of GPS data across southern Taiwan also indicate that the Longitudinal Valley fault is a major active structure (e.g., Hsu et al., 2003). Contributions to strain accumulation by the Central Range fault, however, are not yet clear.

\section{The November 1951 earthquake series}

The major shocks of 25 November occurred at 02:47 and 02:50, local time (Taiwan Weather Bureau, 1952). Since they occurred just 3 min apart and only ten seismic stations were operating in Taiwan at that time, widely disparate source parameters have been calculated and reported for the earthquakes (e.g., Taiwan Weather Bureau, 1952; Gutenberg and Richter, 1954; Lee et al., 1978; Hsu, 1980; Abe, 1981). The analyses by the Taiwan Weather Bureau (1952) and Hsu (1980) indicate the first one was the larger of the two, whereas the catalog of Lee et al. (1978) indicates the opposite. In the catalogs of Gutenberg and Richter (1954) and Abe (1981), the two events appear as a single earthquake. Epicentral locations vary widely among these reports and are commonly very far from known faults of the Longitudinal Valley.

Recently, Cheng et al. (1996) tried to use limited information from S-P times reported by the Taiwan Weather Bureau (1952), a Monte Carlo algorithm and information about the surface faults and maximum ground motion amplitudes to relocate the epicenters and calculate the magnitudes of the two events. They placed the hypocenter of the first shock at $23.1^{\circ} \mathrm{N}$ and $121.225^{\circ} \mathrm{E}$, at a depth of $16 \mathrm{~km}$ (Fig. 2). Their hypocenter for the second shock is at $23.275^{\circ} \mathrm{N}$ and $121.35^{\circ} \mathrm{E}$, at a depth of $36 \mathrm{~km}$. They also found that the magnitude of the second shock was larger than that of the first shock $\left(M_{\mathrm{w}}=7.0\right.$ vs. $\left.M_{\mathrm{w}}=6.2\right)$. Although their results still have large uncertainties, they are much better constrained than the previous reports, and their results clearly show that the two earthquakes are related to mapped faults of the Longitudinal Valley. Moreover, they derived focal mechanisms using the first motions reported by the Taiwan Weather Bureau (1952) and Hsu's (1962) map of the surface ruptures. They concluded that the first shock was generated by a thrust fault with a subordinate left-lateral component, striking $\mathrm{N} 32^{\circ} \mathrm{E}$ and dipping $70^{\circ} \mathrm{S}$. From more limited first-motion information, they concluded that the second shock originated on a left-lateral strike-slip fault with a subordinate thrust component.

The surface ruptures of the earthquakes have never been mapped in detail. The most widely accepted version is depicted in Fig. 3, after Hsu (1962). In this representation, the fault extends approximately $40 \mathrm{~km}$ from about $10 \mathrm{~km}$ south of Kuangfu to just north of Fuli (Fig. 3). Since this line runs through the town of Yuli, Hsu named it the Yuli fault and considered it to be the rupture that caused both of the November 1951 earthquakes. Also, on the same map he drew another line just south of the Yuli fault, extending about $20 \mathrm{~km}$ from around Fuli to near Kuanshan. He named this the Chihshang fault and believed it to be an active fault, by virtue of its clear and young topographic appearance. However, Cheng et al. (1996) suggested that Hsu's Chihshang fault also ruptured in 1951. They suggested that the Chihshang fault ruptured during the first shock and that the Yuli fault ruptured during the second shock.

Several important questions arise from these earlier efforts. Did the Chihshang fault rupture during the earthquakes as proposed by Cheng et al. (1996)? If so, how far north did the rupture extend? And was the Chihshang rupture contiguous with the Yuli rupture? If both structures ruptured, are they parts of the same fault? If not, what is the relationship between them? And finally, what are the relationships between the Yuli and Chihshang ruptures and the Longitudinal Valley fault? Are they along two segments of the Longitudinal Valley fault? Or, are they ruptures of faults that are distinct from the Longitudinal Valley fault? What is the implication of the fact that the Yuli fault runs through the town of Yuli, very far from the western mountain front of the Coastal Range? In our attempt to re-evaluate the November 1951 ruptures, our main goal has been to answer these questions.

\section{Re-evaluation of the November 1951 ruptures}

We have been able to determine the location of the November 1951 ruptures in many places. Our re-evaluation leads us to divide the ruptures into three separate strands 




Fig. 3. Map of published surface ruptures of the November 1951 earthquakes, after Hsu (1962). Hsu (1962) concluded that the Yuli fault (in red) is the source of the 1951 earthquakes, and that the Chihshang fault (in blue) is an active fault that did not rupture in 1951. Cheng et al. (1996), on the other hand, suggested that sinistral reverse slip on the Chihshang fault produced the first of the two earthquakes and that similar slip on the Yuli fault produced the second earthquake. White stars are relocated epicenters of the November 1951 earthquakes, after Cheng et al. (1996), with their uncertainties shown as dashed circles.

(Fig. 2), which we call the Chihshang, Yuli, and the Rueisuei ruptures. The Chihshang rupture is similar to the Chihshang fault first noted by Hsu (1962). The Yuli and Rueisuei ruptures are roughly coincident with his Yuli fault, but we believe they constitute two entirely different structures.

\subsection{The Chihshang rupture}

The southern end of the Chihshang rupture is approximately $4 \mathrm{~km}$ south of the town of Chihshang (Chung, 2003; Fig. 4a). Although Hsu (1962) did not document surface rupture near Chihshang during the November 1951 earthquakes, we believe that surface rupture did occur there, since many of the local residents in villages around Chihshang we interviewed did witness surface rupture there, along the western foothills of the Coastal Range. This is also consistent with the reports of damage and destruction around Chihshang in many local newspapers after the earthquakes (Yang, 1953; Chung, 2003). Moreover, this makes a lot more sense, since the southernmost point of the rupture mapped by Hsu (1962) lies very far northeastward from the relocated epicenter of the first shock in the November 1951 series, even after the large uncertainty of the relocation was taken into consideration (Fig. 3). Many recent large strike-slip earthquakes, such as the 1992 Landers, 1999 Izmit, and 1999 Hector Mine earthquakes, have epicenters on or very close to surface ruptures (e.g., Sieh et al., 1993; Barka, 1999; Treiman et al., 2002). Thus it is reasonable to find surface rupture near Chihshang, which is much closer to the epicenter of the first shock, for an earthquake with a significant strikeslip component.

Our interviews indicate that the southern end of the Chihshang rupture was near the small village of Wanan (Fig. 4a). Local witnesses told us that the surface rupture stopped and did not extend onto mapped structures south of Wanan. From Wanan north to near Fuli, more than ten photographs and the results of our interviews suggest almost continuous rupture along the eastern edge of the Longitudinal Valley. Our interviews indicate that the largest vertical offset along this segment was about $0.5 \mathrm{~m}$, with smaller left-lateral offset. Around Fuli, several photographs suggest that the surface ruptures were characterized by en echelon cracking, and that vertical displacements were smaller, less than $0.2 \mathrm{~m}$, with the eastern side moving upward. Left-lateral offset appears to be more obvious, according to newspaper reports collected by $\mathrm{Yu}$ (1997). Farther north, between Chutien and Tungli, vertical displacement was much larger, approximately $1-1.5 \mathrm{~m}$, and the rupture appears to be continuous again. We have found an old photograph of a locality near the Yuli Convalescent Hospital, in which the rupture exhibits a scarp about $1.5 \mathrm{~m}$ high (Fig. 4b). This scarp is only $1 \mathrm{~m}$ high now, due to agricultural modifications (Fig. 4c).

North of Tungli, we did not find undisputable evidence for rupture in 1951. Based upon various newspaper reports, published shortly after the earthquake, that the Yuli railroad bridge was offset and broken by the earthquake, $\mathrm{Yu}$ (1997) suggested that the rupture ran through the bridge about $200 \mathrm{~m}$ west of the bridge's eastern end (Fig. 4a), with offsets about $0.1-0.3 \mathrm{~m}$ vertically and $0.3-0.4 \mathrm{~m}$ left-laterally. However, no other document confirms the existence of the rupture there. Yang (1953) mentioned that there were cracks in the Hsiukuluan River bed, but without photographs or eyewitness accounts, we are uncertain whether the cracks were in fact fault ruptures. The bridge did break during the earthquake, but this may have been due to seismic shaking rather than surface rupture. Since Yu (1997) has analyzed a large collection of reports and appeared to be very confident about this location and he did provide 

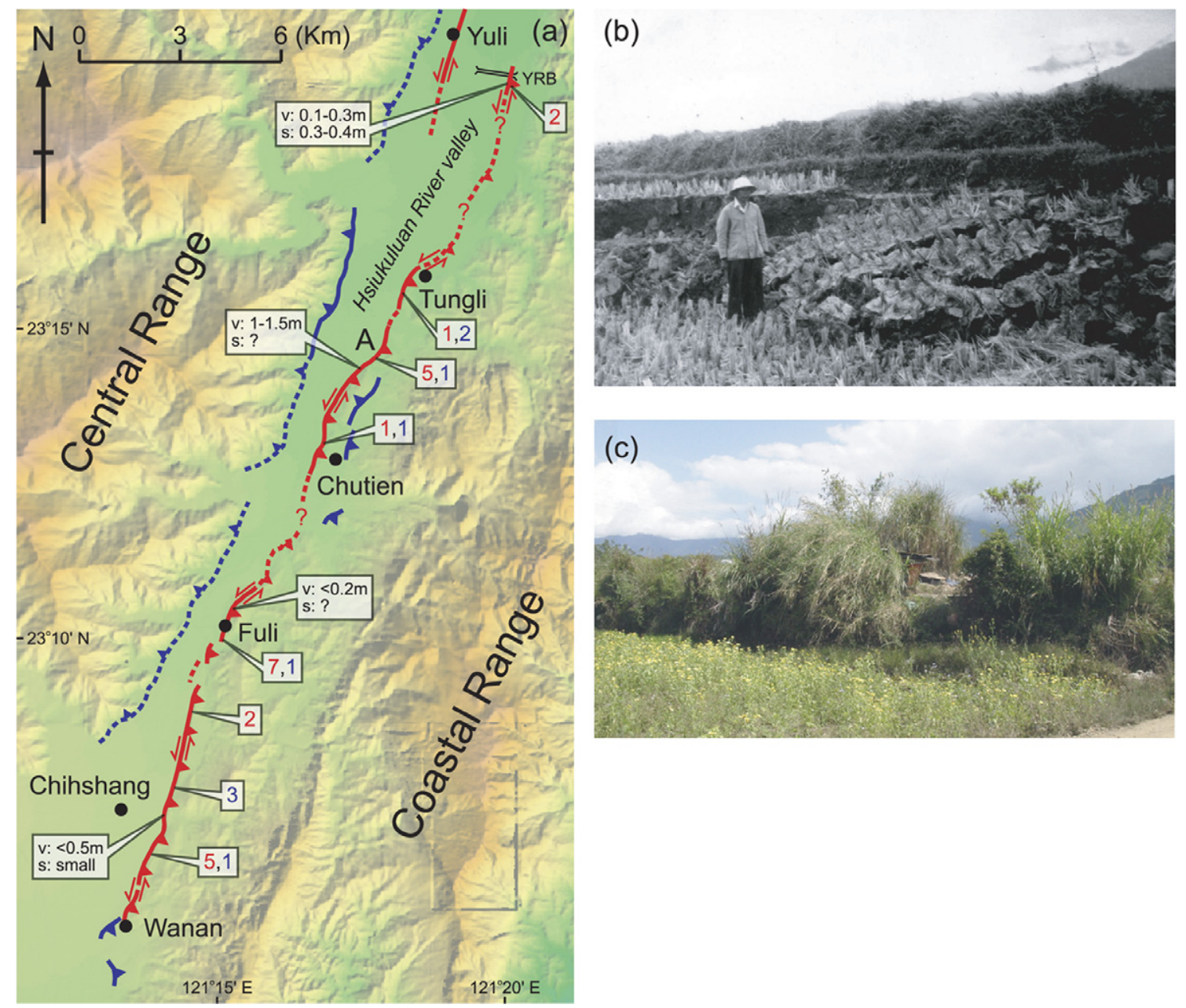

Fig. 4. (a) Map of the Chihshang rupture (in red). Blue lines are active structures that did not rupture in 1951. Modified from Shyu et al. (2005b) and unpublished results of J.B.H. Shyu and L.-H. Chung. YRB: Yuli railroad bridge. For each section of the rupture a few kilometers long, numbers of photographs showing ruptures or cracks (in red) and interview results of actual surface break (in blue), together with offset values (v, vertical; s, sinistral), are also shown. (b) An old photograph of the rupture at point A, between Chutien and Tungli, shows approximately $1.5 \mathrm{~m}$ vertical offset that occurred during the earthquake. The photograph was taken by T.L. Hsu, looking toward the east, and was provided by M.-S. Lin. (c) A recent photograph taken at the same location, also looking toward the east. The scarp is only $1 \mathrm{~m}$ high at present due to modifications associated with agriculture.

detailed information about the offset, we favor his suggestion.

Our interviews indicate that the rupture did not extend north of the Yuli railroad bridge (Fig. 4a). Although Cheng et al. (1996) maintained that their photograph on Plate I-3, which shows rupture with $\sim 0.6 \mathrm{~m}$ vertical offset, to be from a point north of the Yuli railroad bridge, the location of the photograph has been strongly questioned (e.g., Yu, 1997; Chung, 2003).

It is quite clear that the Chihshang rupture occurred on a segment of the Longitudinal Valley fault. The fault has long been known to be an oblique-slip fault, with a significant component of vertical movement (e.g., Hsu, 1962; Ho, 1986, 1988; Chen, 1988). The Chihshang rupture had a similar sense of oblique slip. Based upon geomorphic evidence, Shyu et al. (2005b) mapped the major strand of the Longitudinal Valley fault along the eastern edge of the Longitudinal Valley. East of Chihshang, this strand follows a clear, almost linear scarp about $20 \mathrm{~m}$ high. This is exactly coinci- dent with surface ruptures of 1951. Along this reach, the fault has been rapidly creeping, at rates up to $20 \mathrm{~mm}$ yr-1, for at least 20 years (e.g., Yu and Liu, 1989; Chu et al., 1994; Angelier et al., 1997; Chow et al., 2001; Lee et al., 2001). Our discovery of 1951 ruptures here demonstrates that the fault fails both by creep and by seismic rupture.

North of Fuli, the hanging-wall block of the Longitudinal Valley fault exhibits a series of anticlinal hills and backthrusts (Yang, 1986; Chung, 2003; Shyu et al., 2005b). Although the 1951 ruptures was coincident with the Longitudinal Valley fault there, along the westernmost edge of these hills, we have no evidence that the folds and backthrusts in the hanging-wall block of the fault moved during the earthquakes.

In summary, the Chihshang rupture of 1951 occurred along an up to $30 \mathrm{~km}$ length of the Longitudinal Valley fault. The ruptures were characterized by oblique offset, similar to the sense of slip along the fault depicted on geologic maps (e.g., Chen, 1988; Ho, 1988) and monitored 
during the past 20 years. Along most of its length, the vertical offset along the rupture was less than $0.5 \mathrm{~m}$, but along the Tungli-Chutien section, it was as much as $1.5 \mathrm{~m}$. We are uncertain about the total length of this rupture, but it was at least $20 \mathrm{~km}$ and no longer than $30 \mathrm{~km}$.

\subsection{The Rueisuei rupture}

Like the Chihshang rupture, the Rueisuei rupture followed the western edge of the Coastal Range, along the eastern side of the Longitudinal Valley (Fig. 5a). Sense of slip on the rupture appears to be oblique, with significant amounts of vertical offset. For example, Hsu (1962) reported that at one location, the slickensides on the fault plane showed $1.63 \mathrm{~m}$ of left-lateral offset and $1.3 \mathrm{~m}$ of vertical offset. However, in most of the photographs we have found, there is no way to resolve a left-lateral component. Vertical offset, on the other hand, is usually clear and greater than $1 \mathrm{~m}$, with a maximum of $2.1 \mathrm{~m}$. Most of the rupture scarps are still visible, and a recent trench across one of them (Fig. $5 b$ ) revealed $0.75 \mathrm{~m}$ of vertical offset during the 1951 earthquakes (Chen et al., 2004).

Our investigation indicates that the northern end of the Rueisuei rupture is near the Tzu-Chiang Prison, but its southern end is more difficult to determine. The southernmost location where we have found evidence for the rupture is near the village of Hekang (Fig. 5a). Although the village of Rueimei was heavily damaged during the earth- quakes with collapse of many houses, none of the local residents we interviewed recalled any surface rupture in or near the village. There were also widespread landslides south of Rueimei during the earthquake, but none are clearly related to fault rupture. Thus, it appears that the southern end of the Rueisuei rupture was located approximately at Hekang.

The Rueisuei rupture was coincident with a topographic break at the western base of the Coastal Range, where, based upon geomorphic evidence, Shyu et al. (2005b) mapped the active strand of the Longitudinal Valley fault. Thus, as with the 1951 Chihshang rupture, the Rueisuei rupture of 1951 occurred along a segment of the Longitudinal Valley fault. The oblique sense of offset along the Rueisuei rupture was similar to the sense of offset along the Chihshang rupture, and in both cases, the 1951 rupture had the same sense of slip as indicated on geologic maps of the Longitudinal Valley fault (e.g., Chen, 1988; Ho, 1988).

\subsection{The Yuli rupture}

The Yuli rupture of 1951 was best documented near the town center of Yuli. Since Yuli was already a medium-sized town when the earthquakes struck, we have found more than five photographs showing the ruptures and earthquake damage. Farther from the town center, the evidence is far more scattered (Chung, 2003).

Unlike the Chihshang and Rueisuei ruptures, which followed mostly the eastern edge of the Longitudinal Valley,

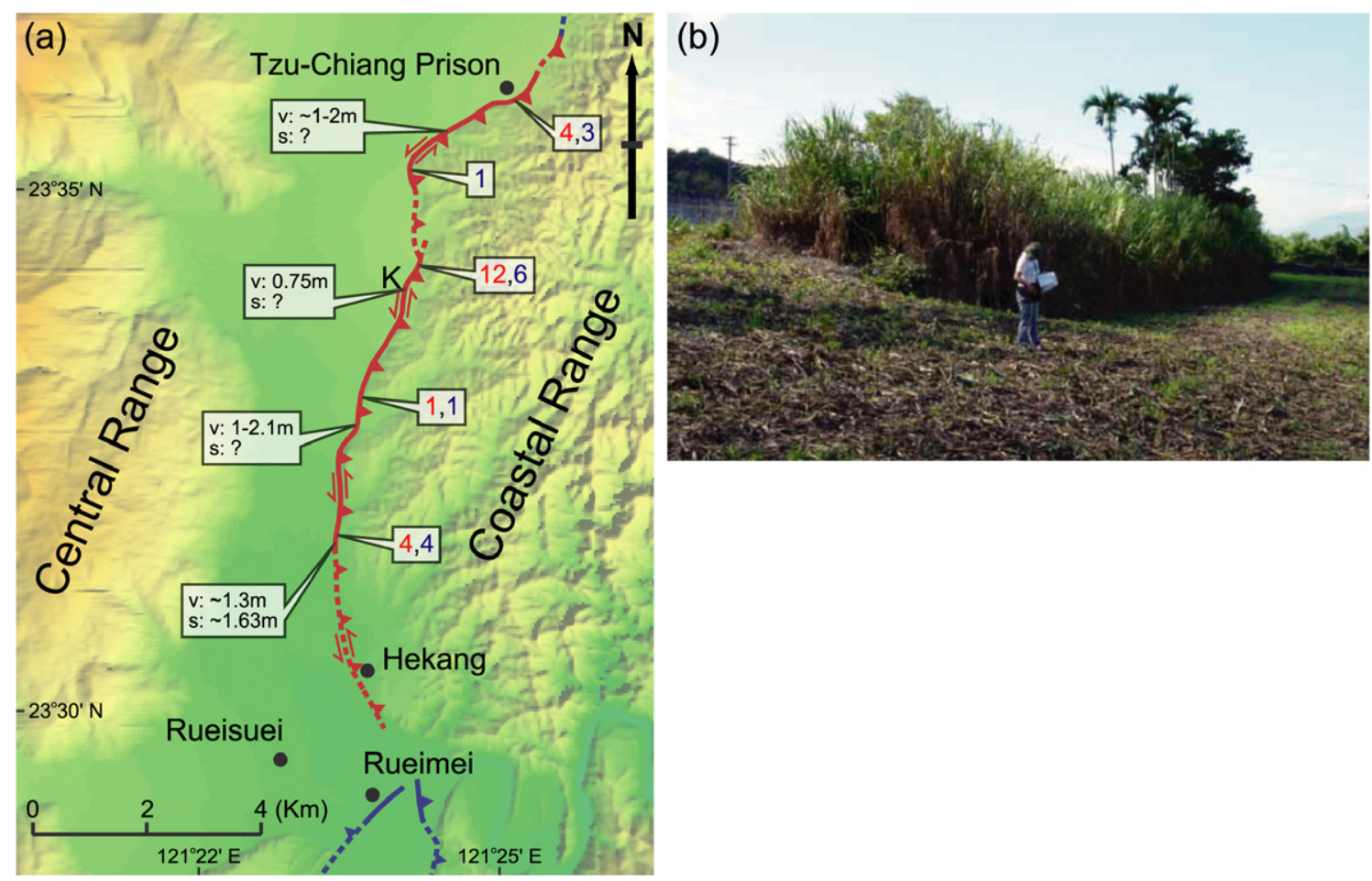

Fig. 5. (a) Map of the Rueisuei rupture (in red). Blue lines are active structures that did not rupture in 1951. Modified from Shyu et al. (2002, 2005b) and unpublished results of J.B.H. Shyu and L.-H. Chung. For each section of the rupture a few kilometers long, numbers of photographs showing ruptures or cracks (in red) and interview results of actual surface break (in blue), together with offset values (v, vertical; s, sinistral), are also shown. (b) A photograph taken at point $\mathrm{K}$ in Fig. 5a, showing the scarp produced in 1951. View is toward the south. A recent trench opened at this location revealed $0.75 \mathrm{~m}$ of vertical offset during the 1951 event (Chen et al., 2004). 
the Yuli rupture lay on the valley floor, in places only $1 \mathrm{~km}$ or so from the Central Range (Fig. 6a). The southern end of the rupture was just south of Yuli. It ran through the town center and destroyed many buildings, including the former Yuli Elementary School (e.g., Hsu, 1962; Bonilla, 1975; Yu, 1997). North of the town center, the rupture probably extended along the Hsiukuluan River bed. Based upon local witnesses and old photographs, we suggest that it extended to a point about $4 \mathrm{~km}$ southeast of Rueisuei (Fig. 6a). The total length of the Yuli rupture is about $20 \mathrm{~km}$. Since we believe the damage of the Yuli railroad bridge was related to the Chihshang rupture, the Yuli rupture was nearly parallel to the Chihshang rupture and stepped about $1.5 \mathrm{~km}$ to the west of the Chihshang rupture near Yuli.

In the town center of Yuli, all of the photographs we have found indicate that the rupture was almost purely leftlateral strike-slip. Although some reports suggested a small vertical component of slip (e.g., Yu, 1997), no vertical offsets are visible in the photographs. One of the most thoroughly documented locations of the rupture was the former Yuli Elementary School (Fig. 6b). The classroom building at the school was offset left-laterally about $0.4 \mathrm{~m}$ (Fig. 6c). However, a row of pebbles at the northern edge of the athletic field of the school was offset only about $0.16 \mathrm{~m}$ (Bonilla, 1975; Fig. 6d). The amount of offset therefore varied significantly in a very short distance within the school grounds (Bonilla, 1975), which is typical for strike-slip faults.

While no document reported the extension of the rupture north from the town center of Yuli, we believe that it extended along the Hsiukuluan River bed to Kuokailiang, approximately $4 \mathrm{~km}$ southeast of Rueisuei (Fig. 6a), where there is a linear ridge about $200 \mathrm{~m}$ long, rising more than $10 \mathrm{~m}$ above a river terrace east of the Hsiukuluan River (Fig. 7a). The landowner, who lives right next to the ridge, recalled ruptures along the eastern side of the ridge during the 1951 earthquake, which may have also extended southward more than $500 \mathrm{~m}$ past the ridge (Yang, 1986; Fig. 7b). Since the long axis of the ridge trends toward the ruptures in Yuli, we wonder whether or not the surface ruptures were continuous between these two locations. In fact, we have found a couple of photographs showing features that may represent surface ruptures in the riverbed, between Yuli and Kuokailiang and east of the village of Sanmin (Yu, 1997; Figs. 7c and d). Therefore, we believe the Yuli rupture may well have traversed the riverbed from Yuli to Kuokailiang ridge, a distance of about $16 \mathrm{~km}$.

North of Kuokailiang, there is no evidence for the Yuli rupture. Although the Yuli and Rueisuei ruptures were originally mapped by Hsu (1962) as a single Yuli fault, and most of the later investigations (e.g., Yu, 1997; Cheng et al., 1996; Lin et al., 2000) followed this interpretation, we found no evidence that the Yuli rupture was continuous with the Rueisuei rupture. In fact, our mapping of tectonic landforms (Shyu et al., 2005b) shows that the two ruptures occurred on two distinct faults. First, the Yuli rupture traversed the Longitudinal Valley floor, whereas the Rueisuei rupture ran along the eastern edge of the valley. More importantly, the style of offset on the two ruptures differed markedly. Offsets along the Yuli rupture were almost pure left-lateral strike-slip, while offsets on the Rueisuei rupture were oblique-slip, with a distinct vertical component. This difference in style of offset may well be the reason why documentation was more sparse along the Yuli rupture; the moletracks and en echelon cracks of strike-slip ruptures are generally more subtle to the untrained eye than the scarps of dip-slip faults.

\subsection{The Yuli rupture and the Longitudinal Valley fault}

We argue that the Yuli rupture, unlike the Chihshang and Rueisuei ruptures, is not part of the Longitudinal Valley fault. Co-seismic offsets along both the Chihshang and Rueisuei ruptures were oblique-slip, as is the long-term movement along the Longitudinal Valley fault (e.g., Chen, 1988; Ho, 1988), whereas the Yuli rupture had predominantly left-lateral offset. Moreover, there was a $1.5 \mathrm{~km}$ left step between the Chihshang and Yuli ruptures.

Based upon geomorphic evidence, Shyu et al. (2005b) have mapped the major active strand of the Longitudinal Valley fault between Yuli and Rueisuei (Fig. 6a). This active strand runs approximately along the eastern side of the Longitudinal Valley, about $1.5 \mathrm{~km}$ east of the Yuli rupture. Although this active fault strand is obvious geomorphically, it did not break during the 1951 earthquake. We have found neither documents nor photographs showing rupture along any of the topographic scarps along this strand, and none of the residents we interviewed recalled any surface ruptures on this side of the Longitudinal Valley between Yuli and Rueisuei. Although not as heavily populated as Yuli in 1951, there were many small villages on the eastern side of the Longitudinal Valley, most of them along the mapped strand of the Longitudinal Valley fault. Therefore, it is unlikely that any surface rupture would have gone unnoticed, even if the offset had been small. By contrast, there are many photographs showing very subtle surface deformation from even more sparsely-populated areas along the Chihshang, Rueisuei and Yuli ruptures. Thus we believe that the lack of photographs

Fig. 6. (a) Map of the Yuli rupture (in red). Blue lines are active structures that did not rupture in 1951. Modified from Shyu et al. (2005b) and unpublished results of J.B.H. Shyu and L.-H. Chung. Note that near Yuli, the Yuli and Chihshang ruptures were sub-parallel and about $1.5 \mathrm{~km}$ apart. YRB, Yuli railroad bridge. For the sections of the rupture near Yuli and Kuokailiang ridge, numbers of photographs showing ruptures or cracks (in red) and interview results of actual surface break (in blue), together with offset values (v, vertical; s, sinistral), are also shown. (b) Detailed map showing the Yuli rupture at the Yuli Elementary School, modified from Bonilla (1975) and Yu (1997). (c) Offset in 1951 of about $0.4 \mathrm{~m}$ near the classrooms in the Yuli Elementary School, at point X in Fig. 6b. View is toward the east. Modified from Taiwan Weather Bureau (1952). (d) Offset in 1951 of about $0.16 \mathrm{~m}$ at the edge of the athletic field in the Yuli Elementary School, at point Y in Fig. 6b. View is toward the east. Modified from Bonilla (1975). 
showing surface rupture along this strand indeed indicates that there was no surface rupture along this part of the Longitudinal Valley fault.

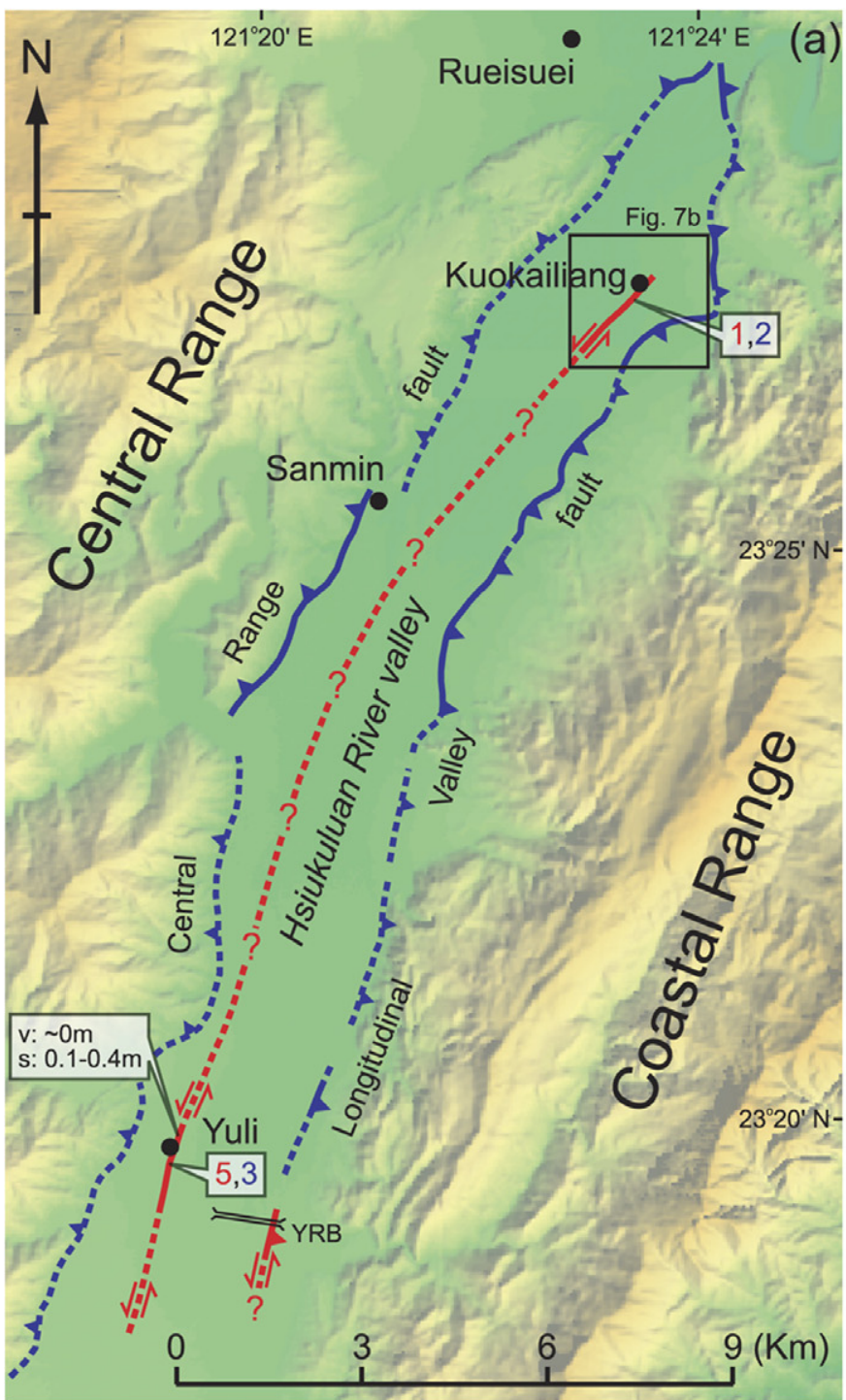

(c)



Of course, this segment of the Longitudinal Valley fault might have ruptured at depth during the November 1951 earthquakes, but the rupture did not reach the surface. No

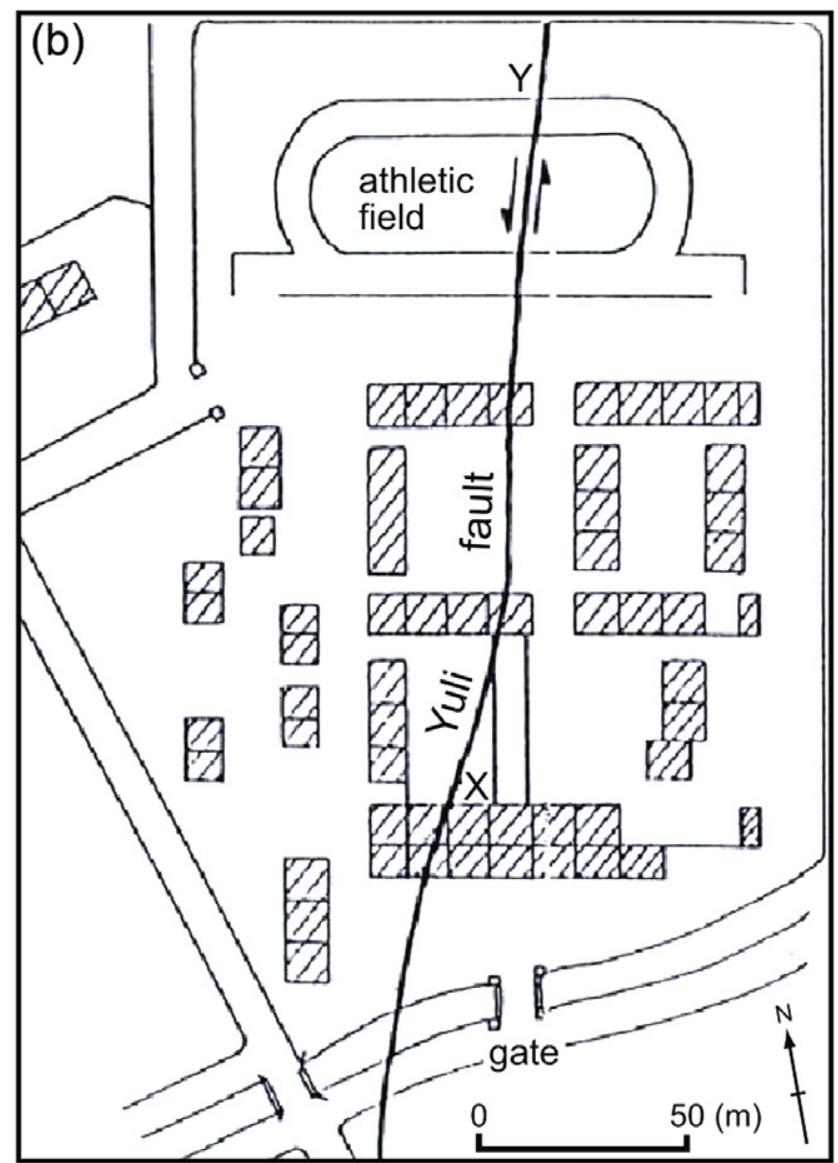

(d)

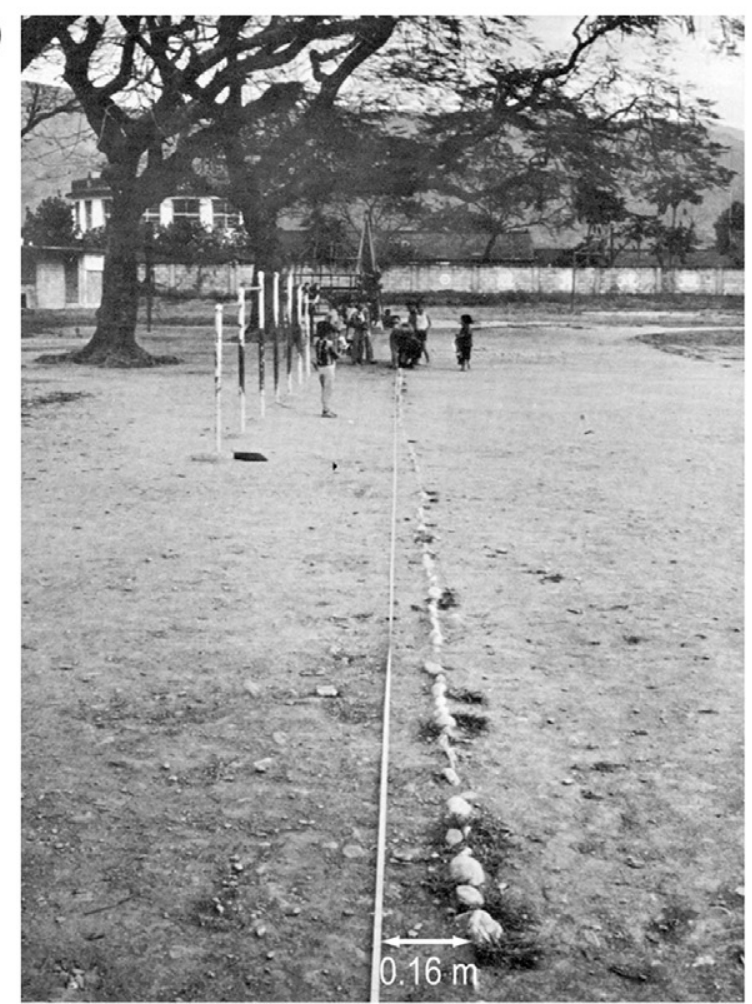


(a)
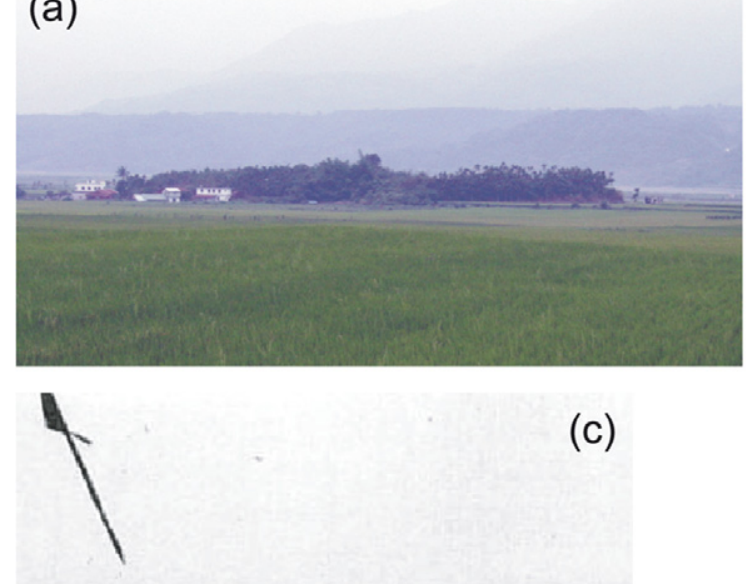

(c)

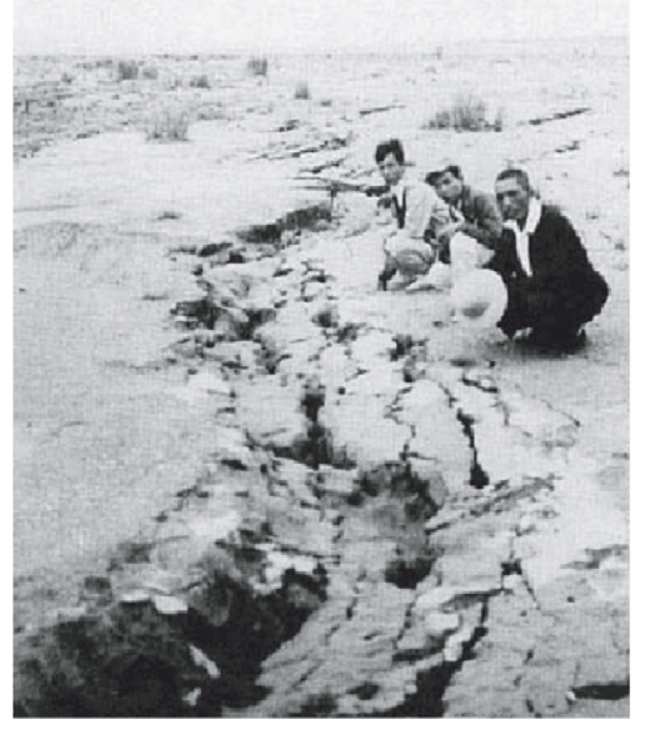

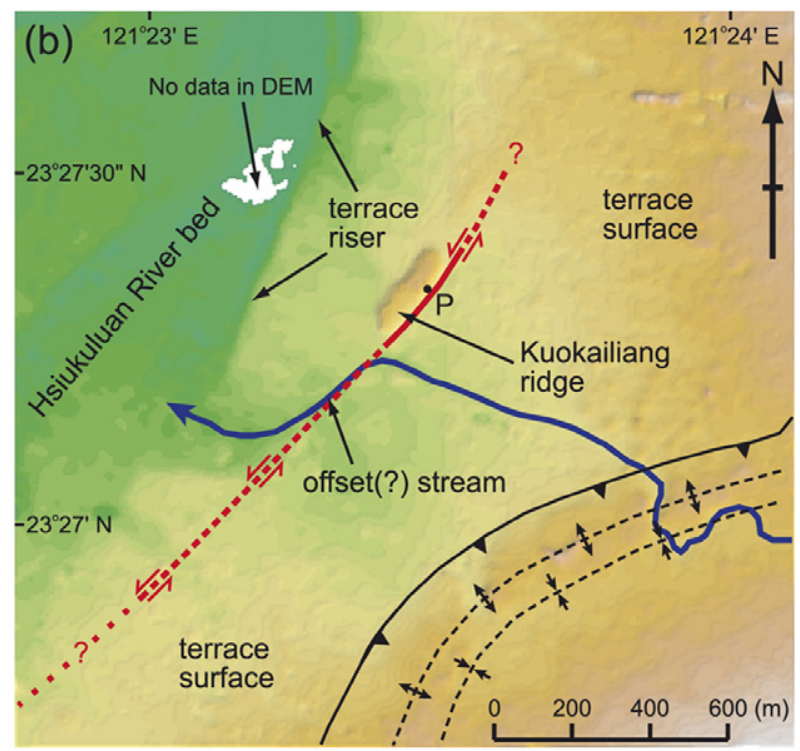

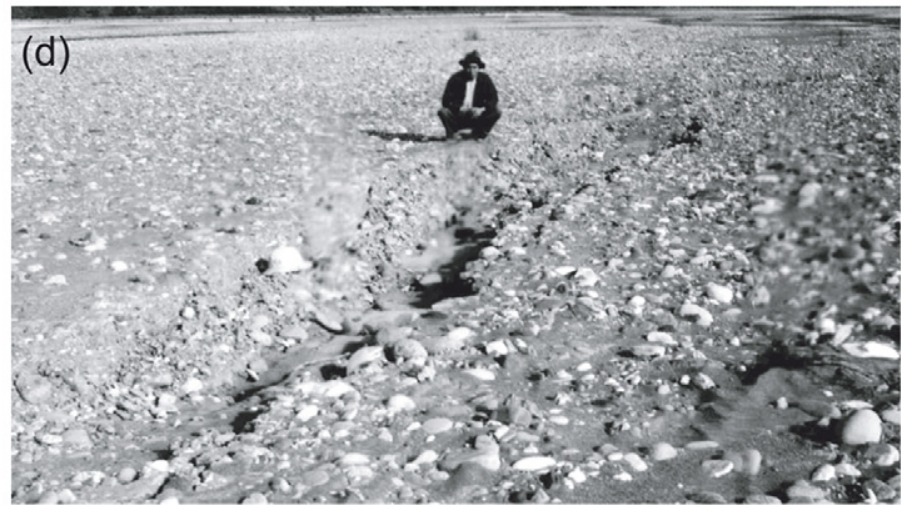

Fig. 7. Proposed extrapolation of the Yuli rupture of 1951 north of Yuli. (a) Kuokailiang ridge, about 4 km southeast of Rueisuei, is a linear ridge about $200 \mathrm{~m}$ long and more than $10 \mathrm{~m}$ high above a river terrace (b) A shaded relief map of the Kuokailiang ridge area. The ridge rises above the terrace surface, and the 1951 Yuli rupture (in red) ran along the eastern side of the ridge. Dashed sections are based on the recollection of the landowner of Kuokailiang ridge, and the dotted section is our extrapolation. The Longitudinal Valley fault and secondary folds in its hanging-wall block (in black), which did not rupture in 1951, lie several hundred meters east of the ridge. South of the ridge, a small stream that flows into the Hsiukuluan River appears to be offset left-laterally for about $400 \mathrm{~m}$. (c) Ruptures in the riverbed, perhaps near and east of the village of Sanmin. View is toward northeast. From Yu (1997). (d) Another photograph of ruptures in the riverbed north of Yuli. The photograph was taken by T.L. Hsu and provided by M.-S. Lin.

reliable seismologic information, such as relocated aftershocks, is available to verify or disprove this. However, since the well-documented part of the Yuli rupture, within the town center of Yuli, was clearly separate from and subparallel to the mapped strand of the Longitudinal Valley fault, any attempt to connect the Yuli rupture back to the fault would be geometrically difficult. Thus we believe that the Yuli rupture is wholly separate from this part of the Longitudinal Valley fault.

Instead, the Yuli rupture appears to traverse the Hsiukuluan River bed to Kuokailiang ridge. When mapping the active structures in the Longitudinal Valley, Shyu et al. (2005b) interpreted the ridge to be the product of a strikeslip fault west of the Longitudinal Valley fault. The mapped strand of the Longitudinal Valley fault, with its obvious reverse fault landforms, such as secondary folds in its hanging-wall block, lies about several hundred meters east of the ridge (Fig. 7b). We believe that the ridge is not formed by another strand of the fault, since it is symmetrical: Both its western and eastern slopes above the river terrace are steep and similar in height. This is distinct from the secondary folds found along the Longitudinal Valley fault. Rather, it resembles a "pressure" ridge, like those typically found along strike-slip faults. Moreover, the November 1951 rupture ran along the eastern side of the ridge. If the ridge is indeed formed by movements along an east-dipping strand of the Longitudinal Valley fault, the rupture would have been along its western side.

A small outcrop in Kuokailiang ridge (point $\mathrm{P}$ in Fig. 7b) reveals that the top of fluvial gravels underlying the ridge surface is currently several meters higher than the surrounding terrace surfaces (Chung, 2003; L.-H. Chung and J.B.H. Shyu, unpublished data). This indicates at least several meters of vertical separation between the ridge and the 
surrounding terraces. For a fault that is dominantly strikeslip, this amount of total vertical offset suggests at least several tens of meters of cumulative left-lateral offset. In fact, a small stream that flows into the Hsiukuluan River just south of Kuokailiang ridge appears to be offset left-laterally for about $400 \mathrm{~m}$ (Fig. 7b). Thus the Yuli rupture appears to break along a pre-existing strike-slip fault, with clear evidence for prior strike slip.

One may argue that our interpolation of the Yuli rupture from Yuli to Kuokailiang is rather speculative, and that the surface deformation shown in Figs. 7c and d may be merely secondary effects caused by the shaking of the earthquake. In fact, there are several photographs showing secondary effects, such as sandblows or other liquefaction features. We did not use those photographs since they do not indicate the location of surface ruptures. However, because the ruptures were well-documented both at Yuli and at Kuokailiang, it seems more likely that surface rupture extended between the two locations. Thus the fissures shown in Fig. 7, with their NNE-SSW orientation, may indeed be primary surface ruptures within the riverbed.

\section{Discussion}

\subsection{The November 1951 earthquake series: a complex rupture event}

The November 1951 earthquakes in the Longitudinal Valley constitute one of the most disastrous seismic episodes in the recorded history of eastern Taiwan. Although many kilometers of surface rupture were reported after the earthquake, no detailed map of the ruptures was produced. Most maps depicted the ruptures as occurring along a nearly straight line, with a discontinuity between Fuli and Yuli in some renditions (e.g., Hsu, 1962; Hsu and Chang, 1979; Cheng et al., 1996; Chu and Yu, 1997; Fig. 2). Our reevaluation reveals that, in fact, the ruptures were more complicated. We divide the surface breaks into three separate ruptures: the Chihshang, Yuli, and Rueisuei ruptures, each with its own distinct characteristics. The Chihshang and Rueisuei ruptures occupied separate $30-$ and $15-\mathrm{km}$ long segments of the sinistral reverse Longitudinal Valley fault. The Yuli rupture occurred along a left-lateral fault that traverses the valley floor more than $1 \mathrm{~km}$ west of the Longitudinal Valley fault.

The recent relocation and parameterization of the sources of the two earthquakes by Cheng et al. (1996) are consistent with these rupture patterns. Their hypocenter for the first shock, at 02:47, is approximately at the southern end of the Chihshang rupture (Fig. 2). The focal mechanism of this earthquake shows that the earthquake was generated by a thrust fault with a left-lateral component, striking similarly to the Chihshang rupture. Taking into account the uncertainty, the hypocenter may well be on the east-dipping plane of the Longitudinal Valley fault. Their hypocenter for the second shock, at 02:50, is near the northern end of the Chihshang rupture and the southern end of the Yuli rup- ture. The large uncertainty of the hypocenter means that it could be consistent with rupture along a primarily sinistral Yuli fault. The focal mechanism of this earthquake is poorly constrained, but Cheng et al. (1996) believed that there was a significant left-lateral strike-slip component of the rupture.

We believe that the Chihshang rupture produced the first shock and induced the Yuli and Rueisuei ruptures, which produced the second, larger shock. The lengths of the ruptures help us calculate the moment magnitudes $\left(M_{\mathrm{w}}\right)$ of the two shocks, based upon published regressions of length against magnitude (e.g., Wells and Coppersmith, 1994). The first shock would have a moment magnitude $\left(M_{\mathrm{w}}\right)$ of 6.8 , whereas the moment magnitude of the second shock would have been about 6.9. The magnitude of the first shock would be slightly lower, about 6.6 , if the Chihshang rupture stopped near Tungli and did not extend to the Yuli railroad bridge. The similarity in magnitude of these two shocks is significantly different from that calculated by Cheng et al. (1996), because their calculation was based on the map of Hsu (1962), which shows a much greater difference in the lengths of the Chihshang and combined Yuli/Rueisuei ruptures. Interestingly, Cheng et al. (1996) also tried to calculate another type of magnitude $\left(M_{\mathrm{H}}\right)$, which is defined by Hsu (1971), using the maximum ground motion amplitudes recorded by seismic stations in Taiwan. Their results of $M_{\mathrm{H}}$ are 6.3 and 6.4 for the two shocks. Although these low $M_{\mathrm{H}}$ values may indicate that the two shocks were in fact moderate in size, the unique definition of $M_{\mathrm{H}}$ and the fact that they were based upon seismic data from very few stations (five for the first shock and only two for the second shock) hampered the application of these magnitude values to analyze the rupture length. Similarity in magnitude of the two quakes, however, is supported by the original earthquake report of the Taiwan Weather Bureau (1952), in which the intensity maps for the two shocks have similar peak intensities and areas.

It is well known that earthquakes can be triggered by changes in Coulomb failure stress that result from an earlier earthquake (e.g., Harris, 1998; Stein, 2003). This mechanism has been invoked, for example, to explain the progressive failure of the North Anatolian fault between 1939 and 1999 (e.g., Stein et al., 1997), and to calculate future seismic hazards along the fault (e.g., Hubert-Ferrari et al., 2000; Parsons et al., 2000). In general, after a major earthquake, areas where stress has increased are favored areas for aftershocks and/or subsequent mainshocks to occur (Harris, 1998). In many cases, the areas where stress increases significantly are near the ends of the ruptures (e.g., Hubert-Ferrari et al., 2000; Anderson and Ji, 2003). Since the epicenter of the second shock of the 1951 earthquakes was near the northern end of the first rupture, it might well be in an area where the local stress field changed to promote ruptures. Recently, a Coulomb stress analysis of the 1951 earthquakes was carried out based partly on our reevaluations, and the results of this analysis are consistent with this hypothesis (Chen et al., submitted for publication). Moreover, the Yuli rupture of the second shock lay 
about $1.5 \mathrm{~km}$ west of the Chihshang rupture, which broke during the first shock. The reverse component of slip on the east-dipping Chihshang rupture might have also decreased the normal stress around the Yuli rupture, thus promoting the left-lateral rupture to occur. Such induced rupture events, with different modes of slip due to local stress field change, are exemplified by the Rainbow Mountain-Fairview Peak-Dixie Valley earthquakes of 1954 (e.g., Hodgkinson et al., 1996). There, an $M=7.2$ oblique-slip event triggered failure of an adjacent normal fault in an $M=6.7$ earthquake.

The relationship between the Yuli and Rueisuei ruptures is also complex. There is a gap of approximately $5 \mathrm{~km}$ between these two ruptures (Fig. 2). It is noteworthy, however, that the northern end of the Yuli rupture at Kuokailiang is very close to the unruptured strand of the Longitudinal Valley fault, and may well extend beneath the Longitudinal Valley fault further north (Figs. 2 and 6a). Thus, it is plausible that the Yuli rupture triggered the Rueisuei rupture. This would be reminiscent of what happened during the Enggano, Sumatra, earthquake, which occurred on 4 June 2000 . There, about $65 \%$ of the earthquake's moment was produced by strike-slip rupture on a fault in the downgoing oceanic slab. This was followed by failure of a patch of the overlying subduction interface (Abercrombie et al., 2003).

Another important result of this documentation of the 1951 rupture is that the Longitudinal Valley fault, a fault that is currently creeping at a rate up to $20 \mathrm{~mm}$ yr-1, previously failed seismically. The Chihshang rupture was along a portion of the fault that is well known for its rapid creep behavior (e.g., Yu and Liu, 1989; Angelier et al., 1997; Chow et al., 2001; Lee et al., 2001). Since the fault ruptured during the 1951 earthquake, one might well suspect that currently observed creep is not releasing all strain accumulating in the blocks adjacent to the fault, and that creep should be viewed as retarding rather than eliminating the prospect of future seismic ruptures there. At this moment, we do not have enough information to determine whether or not this dual behavior also characterizes strands of the Longitudinal Valley fault further to the north or to the south. Preliminary geodetic measurements near Rueisuei indicate the fault may creep there, but much more slowly ( $\mathrm{Yu}$ and Liu, 1989). Further investigation is needed to resolve these details of strain accumulation and release along the Longitudinal Valley fault.

\subsection{What is the Yuli fault?}

The Yuli fault was originally proposed by Hsu (1962) in describing the 1951 earthquake ruptures. His definition encompasses both our Yuli and Rueisuei ruptures. His idea was that since the Yuli fault ruptured in 1951, it is probably the main fault of the Longitudinal Valley. Later studies of the Longitudinal Valley, such as those by $\mathrm{Chu}$ and $\mathrm{Yu}$ (1997), Yu (1997), and Lin et al. (2000), all adopted this point of view, mapping the Longitudinal Valley fault through the town of Yuli. This, however, creates geometric problems. The town of Yuli is far from the western foothills of the Coastal Range, where the Longitudinal Valley fault is located. As a result, previous maps show either a significant bend or en echelon step over of the fault south of Yuli. These maps ignore the continuous geomorphic evidence showing that the Longitudinal Valley fault lies along the western Coastal Range front.

In fact, we believe that there are three principal faults in the valley, and portions of two of these ruptured in 1951. No geomorphic or structural evidence supports the geometries of the earlier workers. The sinistral reverse Longitudinal Valley fault is clearly continuous along the entire eastern side of the valley between Taitung and Hualien (Shyu et al., 2005b; Fig. 1b). It does not bend or step over toward the west except at Rueisuei, where the Coastal Range front itself bends.

Therefore, the "Yuli fault" of Hsu (1962) clearly encompasses two different structures. Its northern part, defined by the Rueisuei rupture, is actually a portion of the sinistral reverse Longitudinal Valley fault that is bringing Coastal Range rocks over the Longitudinal Valley. The southern part of Hsu's Yuli fault is the predominantly left-lateral Yuli rupture. Since the northern part of Hsu's (1962) Yuli fault is part of the Longitudinal Valley fault, we propose to retain Hsu's name only for the fault that broke along the Yuli rupture. Thus, we suggest that the term "Yuli fault" hereafter only be used in reference to the Yuli rupture of the 1951 earthquakes. This fault is a sinistral fault that traverses the Longitudinal Valley, with negligible vertical movement.

We are unsure whether or not the Yuli fault dips eastward at depth. If so, it could be an integral part of the obliquely slipping Longitudinal Valley fault zone. However, its location, west of the east-dipping Longitudinal Valley fault, and its predominance of strike-slip movement make such a geometry quite unlikely. Neither is the Yuli fault likely to be part of the Central Range fault system, since the west-dipping fault is west of Yuli. We believe the alternative - that it is a separate, steeply dipping, strike-slip fault that has developed within the sediments of the valley, structurally separate from the Longitudinal Valley fault system (Fig. 8).

One might ask why the Yuli fault exists. During the oblique collision between the Luzon volcanic arc and the Central Range of Taiwan, the Longitudinal Valley suture is absorbing both the convergence between the two, and the northward movement of the docked volcanic rocks of the Coastal Range (e.g., Shyu et al., 2005a,b). Thus the Longitudinal Valley fault is characterized by high rates of both reverse and left-lateral motions. Along the middle part of the Longitudinal Valley, the existence of the predominantly sinistral Yuli fault may indicate that the Longitudinal Valley fault there has a smaller left-lateral component than elsewhere. Topographic features of the Longitudinal Valley fault, in fact, suggest that this may be the case. The extreme linearity of the Chihshang segment of the fault probably 


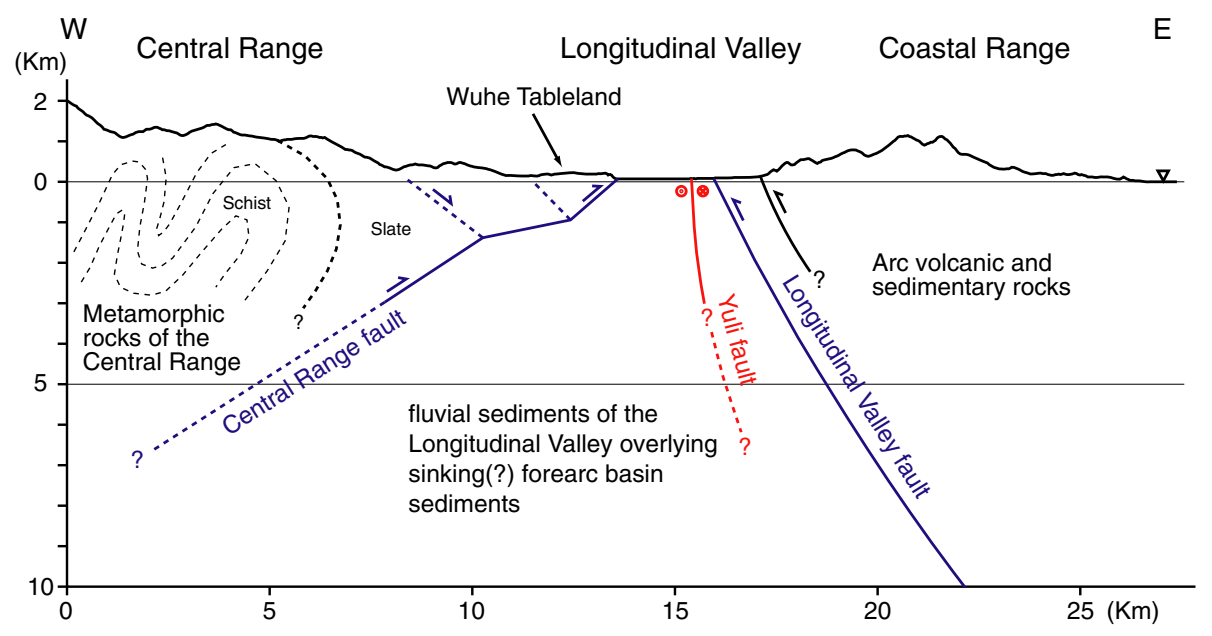

Fig. 8. A schematic tectonic east-west cross section of the Longitudinal Valley at the latitude of the Wuhe Tableland. The west-dipping Central Range fault crops out along the eastern edge of the Central Range and the Wuhe Tableland, but did not ruptured during the 1951 earthquakes. The steeply dipping(?) Yuli fault and sections of the east-dipping Longitudinal Valley fault, on the other hand, ruptured. The Longitudinal Valley fault crops out along the eastern side of the Longitudinal Valley and accommodates uplift and deformation of the terraces along the western flank of the Coastal Range. The Yuli fault is a separate, discontinuous strike-slip fault developed in the sediments of the valley, structurally separate from the Longitudinal Valley fault system. The Longitudinal Valley fault may have a smaller left-lateral component in this segment than elsewhere, and the sinistral Yuli fault appears to accommodate the northward motion of the Coastal Range. Black, inactive fault in basement rocks; Blue, active fault not ruptured in 1951; Red, ruptures of 1951

indicates a large component of strike-slip motion, whereas north of Yuli the fault trace is more irregular, with many secondary anticlines and synclines in its hanging-wall block, typical for structures with larger components of reverse motion (Shyu et al., 2005b). Along-strike difference in behavior has also been suggested for the Longitudinal Valley fault, based upon the significantly different pattern and numbers of relocated small earthquakes along the fault (e.g., Kuochen et al., 2004). Therefore, we suggest that the Yuli fault appears where oblique slip across the Longitudinal Valley has been more effectively partitioned onto two separate faults.

\subsection{Implications for seismic hazard assessment}

Our re-evaluation of the November 1951 ruptures raises many important questions relevant to seismic hazard assessment in the Longitudinal Valley. For example, it is clear that between Yuli and Rueisuei, the Longitudinal Valley fault did not rupture during the 1951 earthquakes. Why did this happen? We have proposed that stress loading on the Yuli fault by failure of the Chihshang segment of the Longitudinal Valley fault promoted failure on the Yuli fault. The stress loading should, in fact, have been even higher for the unruptured segment of the Longitudinal Valley fault between Yuli and Rueisuei, and have brought it closer to failure. A pre-1951, prehistoric-record rupture along this segment may have shed so much stress from the adjacent crust that this segment could not be loaded to the point of failure by the rupture of adjoining segments to the north and south in 1951. Alternatively, it is conceivable that this segment fails entirely by creep. More detailed paleoseismic and geodetic investigations along this segment are needed to resolve this question.
The Chihshang and Rueisuei ruptures clearly represent seismic failure along segments of the Longitudinal Valley fault. However, the two segments are behaving quite differently at present. The Chihshang segment is creeping rapidly, whereas the Rueisuei segment is not. What does this imply about future seismic activity along these two segments? Does the Chihshang segment have a longer average recurrence interval than the Rueisuei segment, or does it just have smaller amounts of offset per earthquake? Again, paleoseismological and geodetic studies along these two segments could address these questions.

The Yuli fault may be the most poorly understood structure in the middle Longitudinal Valley. For example, we do not know whether this fault extends further northward, beneath the Longitudinal Valley fault, or further southward beneath the Central Range fault. Although the Yuli fault appears to have moved previously, there is no constraint on its long-term slip rate. Furthermore, Bonilla (1975) suggested that the Yuli fault might be creeping, but more recent investigations suggest that it is not (e.g., Chung, 2003). A short-aperture geodetic array across this fault should reveal which is the case. Paleoseismic studies could reveal its seismic behavior.

\section{Conclusions}

In our attempt to re-evaluate the ruptures of the November 1951 earthquake series in the Longitudinal Valley, eastern Taiwan, we have analyzed all published documents, and relevant reports and photographs, and we have interviewed more than 40 elderly local residents who have experienced the earthquake. We divide the surface breaks into three separate ruptures from south to north: the Chihshang, Yuli, 
and Rueisuei ruptures. The Chihshang rupture was approximately $30 \mathrm{~km}$ long and probably ruptured during the first shock of the 1951 earthquake series. The length of the Yuli rupture was about $20 \mathrm{~km}$, and the Rueisuei rupture was about $15 \mathrm{~km}$ long. Consideration of epicentral locations and focal mechanisms suggests that the Yuli and Rueisuei ruptures produced the second shock of the November 1951 series. The Chihshang and Rueisuei ruptures occurred along widely separate lengths of the Longitudinal Valley fault, and both experienced oblique-slip movement during the earthquake. The sense of slip along the Yuli rupture, on the other hand, was left-lateral, and the rupture occurred on a fault that traverses the middle of the valley floor and is distinct from the Longitudinal Valley fault. The failure of the Chihshang rupture, which produced the first shock of the November 1951 earthquakes, probably triggered the subsequent failure of the Yuli and Rueisuei ruptures. The active structures in this middle section of Taiwan's Longitudinal Valley are complex - mountain ranges to the east and west are converging on the valley on two opposing reverse faults. The 1951 earthquakes involved partial rupture of just one of these and a strike-slip fault broke the valley sediments in between.

\section{Acknowledgments}

We thank T.-C. Lin and Y. Wang for their assistance with the field work. We are also grateful for valuable discussions with J.-P. Avouac, W.-S. Chen, J.-C. Hu, J.-C. Lin, M.-S. Lin, and Y.-M. Wu. The comments and suggestions of reviewers H.-T. Chu, T.E. Fumal, L. Kirstein, and K. Mueller helped us improve this manuscript significantly. Many old photographs and documents were kindly provided by T.L. Hsu, M.-S. Lin, and S.-N. Cheng. The help of many local residents in eastern Taiwan, especially S.-H. Chang, K.-C. Chiang, L.-P. Tseng, and C.-S. Chang, are greatly appreciated. This work was supported by both the National Science Foundation and the National Science Council. This research was also supported in part by the Gordon and Betty Moore Foundation. This is Caltech Tectonics Observatory Contribution \#2.

\section{References}

Abe, K., 1981. Magnitudes of large shallow earthquakes from 1904 to 1980. Physics of the Earth and Planetary Interiors 27, 72-92.

Abercrombie, R.E., Antolik, M., Ekström, G., 2003. The June $2000 \mathrm{M}_{\mathrm{w}} 7.9$ earthquakes south of Sumatra: deformation in the India-Australia plate. Journal of Geophysical Research 108, 2018. doi:10.1029/ 2001JB000674

Anderson, G., Ji, C., 2003. Static stress transfer during the 2002 Nenana Mountain-Denali Fault, Alaska, earthquake sequence. Geophysical Research Letters 30, 1310. doi:10.1029/2002GL016724.

Angelier, J., Chu, H.-T., Lee, J.-C., 1997. Shear concentration in a collision zone: kinematics of the Chihshang Fault as revealed by outcrop-scale quantification of active faulting, Longitudinal Valley, eastern Taiwan. Tectonophysics 274, 117-143.

Barka, A., 1999. The 17 August 1999 Izmit earthquake. Science 285, 18581859.
Biq, C., 1965. The East Taiwan rift. Petroleum Geology of Taiwan 4, $93-$ 106.

Bonilla, M.G., 1975. A Review of Recently Active Faults in Taiwan. Open File Report 75-41, U.S. Geological Survey, Menlo Park, 58pp.

Bonilla, M.G., 1977. Summary of quaternary faulting and elevation changes in Taiwan. Memoir of the Geological Society of China 2, 43 55.

Chang, C.P., Angelier, J., Huang, C.Y., Liu, C.S., 2001. Structural evolution and significance of a mélange in a collision belt: the Lichi Mélange and the Taiwan arc-continent collision. Geological Magazine 138, 633-651.

Chang, H.-C., Lin, C.-W., Chen, M.-M., Lu, S.-T., 1998. An Introduction to the Active Faults of Taiwan, Explanatory Text of the Active Fault Map of Taiwan. Special Publication of the Central Geological Survey 10, Taipei, 103pp (in Chinese with English Abstract).

Chen, J.-S., 1976. The analysis and design of refraction and reflection seismic survey of the Taitung area. Petroleum Geology of Taiwan 13, 225 246.

Chen, J.-S., Chou, J.-N., Lee, Y.-C., Chou, Y.-S., 1974. Seismic survey conducted in eastern Taiwan. Petroleum Geology of Taiwan 11, 147-163 (in Chinese with English Abstract).

Chen, K.H., Toda, S., Rau, R.-J., submitted for publication. Leaping triggered sequence along a segmented fault: the $1951 \mathrm{M}_{\mathrm{L}} 7.3$ Hualien-Taitung earthquake sequence in eastern Taiwan. Journal of Geophysical Research.

Chen, W.-S., 1988. Tectonic Evolution of Sedimentary Basins in Coastal Range, Taiwan. Ph. D. thesis, National Taiwan University, Taipei, $304 \mathrm{pp}$ (in Chinese).

Chen, W.-S., Yen, Y.-C., Yang, C.-C., Yang, H.-C., Chen, Y.-Q., Tsai, K.-Z., Huang, N.-W., Chu, Y.-G., Chang, H.-C., Lin, C.-W., Lin, W.-H., Liu, Y.-C., 2004. Paleoseismologic studies of the 1951 earthquake rupture, Eastern Taiwan. Special Publication of the Central Geological Survey 15, pp. 137-145 (in Chinese with English abstract).

Chen, Y.-G., Chen, W.-S., Lee, J.-C., Lee, Y.-H., Lee, C.-T., Chang, H.-C., Lo, C.-H., 2001. Surface rupture of 1999 Chi-Chi earthquake yields insights on active tectonics of central Taiwan. Bulletin of the Seismological Society of America 91, 977-985.

Cheng, S.N., Yeh, Y.T., 1989. Catalog of the Earthquakes in Taiwan from 1604 to 1988. Institute of Earth Sciences, Academia Sinica, Taipei, 255pp (in Chinese).

Cheng, S.-N., Yeh, Y.T., Yu, M.-S., 1996. The 1951 Taitung earthquake in Taiwan. Journal of the Geological Society of China 39, 267-285.

Chow, J., Angelier, J., Hua, J.-J., Lee, J.-C., Sun, R., 2001. Paleoseismic event and active faulting: from ground penetrating radar and high-resolution seismic reflection profiles across the Chihshang Fault, eastern Taiwan. Tectonophysics 333, 241-259.

Chu, H.-T., Yu, M.-S., 1997. The Relationships between Earthquakes and Faults in the Taitung Longitudinal Valley. National Science Council Project Report, Project No. NSC-86-2116-M-047-002, Taipei, 133pp (in Chinese).

Chu, H.-T., Lee, J.-C., Angelier, J., 1994. Non-seismic rupture of the Tapo and the Chinyuan area on the southern segment of the Huatung Longitudinal Valley Fault, Eastern Taiwan, Program with Abstracts of the 1994 Annual Meeting of the Geological Society of China, Taipei, pp. 156-160 (in Chinese with English abstract).

Chung, L.-H., 2003. Surface Rupture Reevaluation of the 1951 Earthquake Sequence in the Middle Longitudinal Valley and Neotectonic Implications. M.S. thesis, National Taiwan University, Taipei, 138pp (in Chinese with English Abstract).

Gutenberg, B., Richter, C.F., 1954. Seismicity of the Earth and Associated Phenomena, second ed. Princeton University Press, Princeton, N.J. $310 \mathrm{pp}$.

Harris, R.A., 1998. Stress triggers, stress shadows, and implications for seismic hazard. Journal of Geophysical Research 103, 24,347-24,358.

Ho, C.S., 1986. A synthesis of the geologic evolution of Taiwan. Tectonophysics $125,1-16$

Ho, C.S., 1988. An Introduction to the Geology of Taiwan, Explanatory Text of the Geologic Map of Taiwan, second ed. Central Geological Survey, Ministry of Economic Affairs, Taipei, 192pp. 
Hodgkinson, K.M., Stein, R.S., King, G.C.P., 1996. The 1954 rainbow mountain-fairview peak-dixie valley earthquakes: a triggered normal faulting sequence. Journal of Geophysical Research 101, 25,45925,471 .

Hsu, M.-T., 1971. Seismicity of Taiwan and some related problems. Bulletin of the International Institute of Seismology and Earthquake Engineering 8, 41-160.

Hsu, M.-T., 1980. Earthquake Catalogues in Taiwan (from 1644 to 1979). National Taiwan University, Taipei, 77pp (in Chinese).

Hsu, T.L., 1962. Recent faulting in the Longitudinal Valley of eastern Taiwan. Memoir of the Geological Society of China 1, 95-102.

Hsu, T.L., Chang, H.C., 1979. Quaternary faulting in Taiwan. Memoir of the Geological Society of China 3, 155-165.

Hsu, Y.-J., Simons, M., Yu, S.-B., Kuo, L.-C., Chen, H.-Y., 2003. A twodimensional dislocation model for interseismic deformation of the Taiwan mountain belt. Earth and Planetary Science Letters 211, 287-294.

Hubert-Ferrari, A., Barka, A., Jacques, E., Nalbant, S.S., Meyer, B., Armijo, R., Tapponnier, P., King, G.C.P., 2000. Seismic hazard in the Marmara Sea region following the 17 August 1999 Izmit earthquake. Nature 404, 269-273.

Kuochen, H., Wu, Y.-M., Chang, C.-H., Hu, J.-C., Chen, W.-S., 2004. Relocation of the eastern Taiwan earthquakes and its tectonic implications. Terrestrial, Atmospheric and Oceanic Sciences 15, 647-666.

Lallemand, S., Liu, C.-S., 1998. Geodynamic implications of present-day kinematics in the southern Ryukyus. Journal of the Geological Society of China 41, 551-564.

Lee, J.-C., Angelier, J., Chu, H.-T., Hu, J.-C., Jeng, F.-S., 2001. Continuous monitoring of an active fault in a plate suture zone: a creepmeter study of the Chihshang Fault, eastern Taiwan. Tectonophysics 333, 219-240.

Lee, W.H.K., Wu, F.T., Wang, S.C., 1978. A catalog of instrumentally determined earthquakes in China (magnitude $\geqslant 6$ ) compiled from various sources. Bulletin of the Seismological Society of America 68, 383-398.

Lin, C.-W., Chang, H.-C., Lu, S.-T., Shih, T.-S., Huang, W.-J., 2000. An Introduction to the Active Faults of Taiwan, second ed. Explanatory Text of the Active Fault Map of Taiwan. Special Publication of the Central Geological Survey 13, Taipei, 122pp (in Chinese with English Abstract).

Parsons, T., Toda, S., Stein, R.S., Barka, A., Dieterich, J.H., 2000. Heightened odds of large earthquakes near Istanbul: an interaction-based probability calculation. Science 288, 661-665.

Sella, G.F., Dixon, T.H., Mao, A., 2002. REVEL: a model for recent plate velocities from space geodesy. Journal of Geophysical Research 107 (B4), 2081. doi:10.1029/2000JB000033.

Shih, T.-T., Chang, J.-C., Hwang, C.-E., Shih, C.-D., Yang, G.-S., Sunlin, Y.-M., 1983. A geomorphological study of active fault in northern and eastern Taiwan. Geographical Research 9, 20-72 (in Chinese with English Abstract).

Shyu, J.B.H., Sieh, K., Chung, L.-H., Chen, Y.-G., Wang, Y., 2002. The active tectonics of eastern Taiwan - new insights from the two geomorphic tablelands ("the Feet") in the Longitudinal Valley. EOS, Transactions, American Geophysical Union 83(47), Fall Meeting Supplement, Abstract T61B-1278.
Shyu, J.B.H., Sieh, K., Chen, Y.-G., 2005a. Tandem suturing and disarticulation of the Taiwan orogen revealed by its neotectonic elements. Earth and Planetary Science Letters 233, 167-177.

Shyu, J.B.H., Sieh, K., Chen, Y.-G., Liu, C.-S., 2005b. Neotectonic architecture of Taiwan and its implications for future large earthquakes. Journal of Geophysical Research 110, B08402. doi:10.1029/2004JB003251.

Shyu, J.B.H., Sieh, K., Chen, Y.-G., Chung, L.-H., 2006. Geomorphic analysis of the Central Range fault, the second major active structure of the Longitudinal Valley suture, eastern Taiwan. Geological Society of America Bulletin 118, 1447-1462.

Sieh, K., Jones, L., Hauksson, E., Hudnut, K., Eberhart-Phillips, D., Heaton, T., Hough, S., Hutton, K., Kanamori, H., Lilje, A., Lindvall, S., McGill, S.F., Mori, J., Rubin, C., Spotila, J.A., Stock, J., Thio, H.K., Treiman, J., Wernicke, B., Zachariasen, J., 1993. Near field investigations of the Landers earthquake sequence, April to July 1992. Science 260, 171-176.

Stein, R.S., 2003. Earthquake conversations. Scientific American 288 (1), 72-79.

Stein, R.S., Barka, A.A., Dieterich, J.H., 1997. Progressive failure on the North Anatolian fault since 1939 by earthquake stress triggering. Geophysical Journal International 128, 594-604.

Taiwan Weather Bureau, 1952. The 1951 Earthquake Report. Taiwan Weather Bureau, Taipei, 83pp (in Chinese).

Teng, L.S., 1987. Stratigraphic records of the late Cenozoic Penglai orogeny of Taiwan. Acta Geologica Taiwanica 25, 205-224.

Teng, L.S., 1990. Late Cenozoic arc-continent collision in Taiwan. Tectonophysics $183,57-76$.

Teng, L.S., 1996. Extensional collapse of the northern Taiwan mountain belt. Geology 24, 949-952.

Treiman, J.A., Kendrick, K.J., Bryant, W.A., Rockwell, T.K., McGill, S.F., 2002. Primary surface rupture associated with the $M_{\mathrm{w}} 7.116$ October 1999 Hector Mine earthquake, San Bernardino County, California. Bulletin of the Seismological Society of America 92, 1171-1191.

Wells, D.L., Coppersmith, K.J., 1994. New empirical relationships among magnitude, rupture length, rupture width, rupture area, and surface displacement. Bulletin of the Seismological Society of America 84, 974-1002.

Yang, G.-S., 1986. A Geomorphological Study of Active Faults in Taiwan - Especially on the Relation between Active Faults and Geomorphic Surfaces. Ph.D. thesis, Chinese Culture University, Taipei, 178pp (in Chinese).

Yang, Y.-C., 1953. Earthquakes in Hualien in the latest 41 years. Hualien Literatures 1, 67-71. in Chinese.

York, J.E., 1976. Quaternary faulting in eastern Taiwan. Bulletin of the Geological Survey of Taiwan 25, 63-75

Yu, M.-S., 1997. Active Faults in the Taitung Longitudinal Valley. Ph.D. thesis, National Taiwan University, Taipei, 141pp (in Chinese).

Yu, S.-B., Liu, C.-C., 1989. Fault creep on the central segment of the Longitudinal Valley fault, eastern Taiwan. Proceedings of the Geological Society of China 32, 209-231.

Yu, S.-B., Chen, H.-Y., Kuo, L.-C., 1997. Velocity field of GPS stations in the Taiwan area. Tectonophysics 274, 41-59. 